\title{
Purchasing Intention: A Research on Mobile Phone Usage by Young Adults
}

\author{
Lutfi SURUCU' ${ }^{1}$, Figen YESILADA ${ }^{2}$, Ahmet MASLAKCI ${ }^{3}$
}

Received: May 31, 2020 Revised: June 14, 2020 Accepted: July 03, 2020

\begin{abstract}
The main aim of study is to identify the factors that affect the purchasing intention of young adults. The reference group is an important factor in determining the underlying causes of young adults' purchasing intentions. However, the literature states that young adults prefer to buy brands they trust in order to eliminate the risks that may arise when buying products they may not know. Moving from this perspective, the study proposes a conceptual model that including structural relationships between brand trust, reference group, and purchasing intention. The study aims to contribute to the literature by discussing the moderator role of brand trust in this structure. A series of hypotheses are tested via a survey completed by 749 young people between the ages of 20 and 30 living in Istanbul, Turkey. The data were analyzed with IBM SPSS-23 and AMOS-18 program. In addition to descriptive, reliability, and factor (exploratory and confirmatory) analysis, hierarchical regression analysis was performed to test the research hypotheses. The results show that the reference group positively influences the purchasing intention, and brand trust plays a moderating role in this relationship. The findings are discussed and some practical suggestions are made for mobile phone manufacturers.
\end{abstract}

Keywords: Purchase Intention, Mobile Phone, Brand Trust

JEL Classification Code: M11, M21, M31

\section{Introduction}

Mobile phones entered the world market in 1990s and the sector has become one of the fastest-growing sectors reaching more than three billion users worldwide (Aytekin, Ayaz, \& Tüminçin, 2019). Mobile phones were introduced to the Turkish market in 1994 and by 2016 the number of users reached 125 million (Yiğit, 2019). Currently, active mobile phone usage penetration in Turkey, which has a population of 82.003.882, has increased to $96.6 \%$ (TUIK, 2020). This rapid penetration is due to having Europe's youngest population

${ }^{1}$ First Author and Corresponding Author. Lecturer, Faculty of Business Management, European Leadership University, Famagusta, Northern Cyprus [Postal Address: Gazi Mustafa Kemal Boulevard, Famagusta, 99500, Northern Cyprus] Email: lutfi.surucu@elu.edu.tr 2Manager, Competition Board, Nicosia, Northern Cyprus. Email: fyesilada@hotmail.com

${ }^{3}$ Lecturer, Faculty of Business Management, Cyprus Science University, Kyrenia, Northern Cyprus.

Email: ahmetmaslakci@csu.edu.tr

(c) Copyright: The Author(s)

This is an Open Access article distributed under the terms of the Creative Commons Attribution Non-Commercial License (http://Creativecommons.org/licenses/by-nc/4.0/) which permits unrestricted noncommercial use, distribution, and reproduction in any medium, provided the original work is properly cited. and being the sixth country with the youngest mobile phone users in the world (Bayraktar, Tatoglu, Turkyilmaz, Delen, \& Zaim, 2012).

Consumers are beginning to use mobile phones at an early age and consider their mobile phones as a status symbol (Ogunyemi, 2010; Sousa, Nobre, \& Farhangmehr, 2019). For young people, social networks accessed by using mobile phones are said to create a sense of identity to various social groups (Lorente, 2002). Young people use mobile phones particularly to maintain and develop their social networks and to sustain their social status (Srivastava, 2005).

Local and international mobile phone manufacturers who want to use this high-potential mobile phone market are striving to maintain their competitive advantage with different marketing strategies (Yang, He, \& Lee, 2007). Competition in the mobile phone market is becoming fiercer, especially with the emergence of new competitors (Goh, Jiang, \& Tee, 2016). Therefore, it is becoming increasingly important for producers to attract new customers with their products and create customer commitment (Lin, Wang, \& Hsieh, 2003).

As brands are one of the most important assets of a company (Doyle, 2001), by investing in branding strategies, companies try to establish as well as to maintain brand 
loyalty as a way of gaining customer's trust (Sodano, 2002). Trust leads to brand commitment. Therefore, commitment is part of the process of maintaining and sustaining a valuable and important relationship created with trust. Delgado and Munuera (2005) point out that brand trust creates competitive advantage and results in marketing success. Recent research has also revealed that brand trust has a key role in overcoming crisis situations (Hegner, Beldad, \& Heghui, 2014; Yannopoulou, Koronis, \& Elliott, 2011).

Consumers also want to avoid purchasing risk by making detailed information search. Young adults rely on their peers both to accelerate the decision process and to make right purchasing decisions (Goh et al., 2016). They also have limited capacity to deal with risk and uncertainties compared to mature individuals, and are vulnerable to the pressure of their peers (Nguyen, \& Do, 2020; Park \& Lessig, 1977). In this context, the purchasing decisions are largely influenced by reference groups (Bearden \& Etzel, 1982). Besides, young people also buy products for social recognition, with the aim of making a positive impact on others, obtaining status and attracting attention (Sweeney \& Soutar, 2001). As a result, reference groups are frequently used to guide purchasing decisions (Noguti \& Russell, 2014).

Even though there is considerable research on the social impact of reference groups (Noguti \& Russell, 2014), the reference group's moderating role was under-researched. Therefore, this research is aimed to determine the moderating role of reference group in the relation between two very important concepts, namely, brand trust and purchasing intention.

\section{Literature Review}

\subsection{Brand Trust}

Marketers are trying to establish and maintain a strong link between the consumer and the brand (Kumar, Kesharwani, \& Das, 2016). Brand trust is the main component of this bond to be created (Hiscock, 2001). Branding is often seen as a long and complicated process (Sichtmann, 2007), which develops and accumulates over time (Hawass, 2013) and influenced by previous experience (Rempel, Holmes, \& Zanna, 1985). In this sense, the trust that consumers have in their brands is important since brands maintain long-term relationships with consumers (Hegner \& Jevons, 2016).

The trust in the brand reduces the ambiguity in an environment where consumers feel particularly vulnerable (Agustin \& Singh, 2005). It also motivates consumers to seek a trustworthy brand to remove the risks that might arise when purchasing products (Chaudhuri \& Holbrook, 2001). Thus, the role of trust is to reduce uncertainty and information asymmetry, and to make consumers feel comfortable with their decisions (Chiu, Huang, \& Yen, 2010). In such a case, brand trust emerges as a tool that reduces the risk to the client's decisions and facilitates decision making in uncertainty.

Acting as a bridge between the brand and consumer relationship, brand trust contributes to the consumer's positive thoughts on the brand (Hess \& Story, 2005) and ease the way of developing personal relationship between the consumer and the brand (Sirdeshmukh, Singh, \& Sabol, 2002). Trust relationship in this sense is regarded as a prerequisite for establishing consumer relationships and, thus, facilitating the intention to purchase (Bhattacharya $\&$ Sen, 2003). Brand trust, which reduces ambiguity in particular, generally stimulates impulse buying of consumers and increases the belief of consumers that the brand will fulfill the specified function and it is able to meet their expectations (Chaudhuri \& Holbrook, 2001). Research shows that the level of trust that consumers have in a brand affects their purchasing decisions and the higher the degree of consumer confidence in the brand, the higher the degree of intention to buy (Dehghani, Mohamamdi, Pour, \& Sayeh, 2013).

Brand trust seems to play a key role in marketing relations in terms of increasing marketing success, maintaining and sustaining competitive advantage (Afzal, Khan, Rehman, Ali, \& Wajahat, 2010; Wottrich, Verlegh, \& Smit, 2017). Consequently, brand trust has attracted the interest of researchers in recent years (Alhaddad, 2015).

Research has found that brand trust positively affects purchase (Dehghani et al., 2013; Luk \& Yip, 2008; Sichtmann, 2007; Tsai, Joe, Lin, Chiu, \& Shen, 2015) and there is a significant relationship between the two concepts (Sichtmann, 2007; Zboja \& Voorhees, 2006; Wang \& Lee, 2016). Studies have also found that brand trust has a significant positive effect on WOM communication and intention to purchase (Sichtmann, 2007), stimulates amount of purchase (Luk \& Yip, 2008) and repurchase behavior (Harris \& Goode, 2004). In light of these studies, our first hypothesis is:

H1: Brand trust has a significant positive effect on purchasing intention.

\subsection{Reference Group}

Reference groups are used to define groups that serve as a reference source for an individual, and can therefore directly or indirectly influence one's attitudes and behaviors (Leigh, 1989; Indayani, 2016; Susanto, 2016). This effect varies according to group affiliation, closeness to group members, relation of the individual with the group, and group characteristics (Rehman \& Jamil, 2016) or by type of the group (Puriwat \& Hoonsopon, 2016). Groups such as family, friends and colleagues, who are interacted constantly 
and informally, have more effect on the individual (Susanto, 2016), while religious groups, professional and commercial associations have smaller effect (Bearden \& Etzel, 1982).

Costumers may follow a norm of a group or an opinion leader in their purchasing decisions (Noguti \& Russell, 2014). The reason for this is that costumers use the information derived from a reference group to evaluate their alternatives. Besides, it is evident that marketers and advertisers make effective use of reference group influence (Bearden \& Etzel, 1982), as well as the well-known and appealing people who approve products while describing products consumed in a socially pleasant environment and the use of certain group members as spokespersons in advertisements.

Hsu, Kang and Lam (2006) determined that $80 \%$ of the purchasing decisions of individuals were affected from the referrals of another person. In this sense, costumers believe that information from others is more reliable. In addition, costumers use reference groups to express themselves or to strengthen their egos by making sure that they own a product and that the brand purchased is seen by others (Bourne, 1957; Park \& Lessig, 1977). This effect is exacerbated especially when the products such as mobile phones, automobiles, and sunglasses are consumed and used in public areas (White $\&$ Dahl, 2006). Thus, they consider that individuals have earned a positive and respectful impression on their peers (Puriwat \& Hoonsopon, 2016).

Reference groups have attracted the attention of marketing scholars and practitioners, when social scientists have recognized that reference groups have a significant effect on the behavior of the society (Susanto, 2016). Bourne (1957) compiled a constructive study on the effects of reference groups on purchasing decisions (Leigh, 1989). Today, research in this direction is still being carried out (Indayani, 2016; Susanto, 2016).

Park and Lessig (1977), in their research conducted on housewives and students, found that students were more influenced by reference groups than housewives because they have more social interaction and a large group structure. Studies have shown that reference groups are effective in product choice (Leigh, 1989), costumers make their purchasing decisions in line with the expectations of the group members (Bearden \& Etzel, 1982) and social influence and reference groups effect purchasing decisions (Eze, Chin, \& Lee, 2012; Indayani, 2016; Susanto, 2016). In the light of these findings our second hypothesis is:

\section{H2: Reference groups have a significant positive effect} on purchasing intention.

Consumers rely on their friends and social networks as information sources while making purchasing decisions to avoid cognitive dissonance (Indayani, 2016). In other words, reference groups reduce the risk perceived by the consumers (Rehman \& Jamil, 2016). While the social media platforms facilitate information dissemination (Laroche, Habibi, Richard, \& Sankaranarayanan, 2012), repeated interactions within the group and long-term relationships are critical in building trust (Laroche et al., 2012). Within this context, it is evaluated that reference groups influence the formation of brand trust and they also moderate the relation between brand trust and purchasing decisions. Therefore, the following hypotheses have been developed.

H3: Reference groups have a moderating role on the relationship between brand trust and purchasing intention.

\section{Research Methods and Materials}

\subsection{Measures}

Data for the study were collected by using a questionnaire with five parts. The first part consists of 10 questions to understand the demographic profile of the respondent. The independent variable in our model - brand trust - was measured using the scale consisting of three items developed by Şimşek and Noyan (2009), who have also conducted their research on the use of mobile phones in Turkey. The scale developed by Marangoz (2013) was used to determine the purchase intention, which is the dependent variable of the research. Finally, reference group effect was measured using the five-item scale adopted from Permatahati (2013). All items in the questionnaire, except the demographic questions, were measured with five-point Likert scale (" $1=$ totally disagree to $5=$ totally agree").

\subsection{Data Collection and Sample}

A pilot study was conducted with 40 people. Adjustments were made according to the feedback of the respondents and the questionnaire was distributed to 30 people and was found reliable (Cronbach's Alpha $=.81$ ).

According to the TUIK data, the population of Turkey is $81,867,223$, young adults between the ages of 20 and 30 represent 13,742,230 of the population (TUIK, 2020). Data were gathered by using structured questionnaire from 20 30 year old young adult consumers through convenience sampling. A total of 1,000 questionnaires were distributed and 749 usable questionnaires were returned, with a response rate of $75 \%$.

The demographic profile of the respondents are as follows: $57,4 \%$ male and $42,6 \%$ female, $21 \%$ married and $79 \%$ single, $33,5 \%$ between the ages of 20 and $23,43,7 \%$ between the ages of 24 and $27,22,8 \%$ between the ages of 28 and $30,34 \%$ with primary or secondary education, $60,5 \%$ with a bachelor degree and $5.5 \%$ with a graduate degree, $53.4 \%$ have a monthly income less than TL2,000, 29.2\% 
between TL2,000 and 3,000, 12\% between TL3,001 and 4,000 and $5.3 \%$ TL 4,001 and more. $70.9 \%$ of the respondents are currently using either Samsung or iPhone $(44.2 \%$ and $26.7 \%$ respectively). While $7.1 \%$ use General Mobile (GM), $6.3 \%$ use LG and $11 \%$ use other brands including HTC, Nokia and Asus. $69.6 \%$ of the participants stated that they have bought a new mobile phone within the last two years.

\subsection{Findings}

Principle components analysis with varimax rotation was used to determine the structural validity of the scale. Kaiser-Meyer-Olkin (KMO) sample adequacy and Bartlett's test of sphericity values were found to be sufficient for the factor analysis $(0.838$ and $\mathrm{p}<0.001$ respectively). Items with eigenvalues of one or greater were extracted and factor loadings lower than 0.40 and those with crossloading were excluded from further analysis. Four factors explaining $71.35 \%$ of the total variance were extracted and the Cronbach's Alpha coefficients of all factors were above 0.70 (Table 1).

\subsubsection{Confirmatory Factor Analysis (CFA)}

Confirmatory factor analysis (CFA) was conducted to test the construct validity of the research variables. In the test, maximum likelihood estimation of the covariance matrix was used. We tested one-factor model and found the model significant (Chi-square $\left(\chi^{2}\right)=224,175, \mathrm{p}<.01$; "Degrees of freedom (df)" $=70$, "goodness of fit $[\mathrm{GFI}] "=.957$, "comparative fit index [CFI]" = .971, "root mean square error of approximation [RMSEA]" $=.054$, "incremental fit index $[\mathrm{IFI}] "=.971,[\mathrm{CMIN} / \mathrm{DF}]=3.202$.

We examined the internal consistency, the convergent and discriminant validity of the constructs to test the measurement model. Table 1 shows that internal consistency reliabilities ( $\boldsymbol{\alpha})$ for each of the latent variables exceeded 0.70 , suggesting good reliability (Mackenzie, Podsakoff, \& Podsakoff, 2011). The square root of average variance extracted (AVE), a measure of convergent validity, for each construct was greater than the recommended level 0.5 (Table 2). In addition, Table 1 shows that all the retained items had loadings greater than the recommended 0.7 cutoff, and that items loaded well on their respective factors. These test results demonstrate good convergent validity. To assess discriminant validity, we used multiple techniques. First, through chi-square difference test, it was confirmed that correlations between each pair of constructs were significantly different from unity. Second, we observed the correlation matrix in Table 2, finding that the largest correlation was 0.58 , less than recommended 0.71 (MacKenzie et al,. 2011). Also, these construct correlations were lower than the square root of AVE of their respective constructs (Fornell \& Larcker 1981). All of these test results suggest good discriminant validity.

Table 1: Factor Analysis Results

\begin{tabular}{|c|c|c|c|}
\hline Factor labels and statements & \multicolumn{3}{|c|}{ Factor Loading } \\
\hline \multicolumn{4}{|l|}{ Brand Trust } \\
\hline BT1- I trust the brand of my phone. & 0.872 & & \\
\hline BT2- I believe this brand will give me the best service. & 0.843 & & \\
\hline BT3- I believe this brand will not disappoint me. & 0.749 & & \\
\hline \multicolumn{4}{|l|}{ Purchase intention } \\
\hline PI12- I will buy this mobile phone brand constantly. & & 0.868 & \\
\hline PI10- If I buy a new mobile phone, I would prefer this brand again. & & 0.839 & \\
\hline PI11- I will continue to use this brand mobile phone & & 0.810 & \\
\hline \multicolumn{4}{|l|}{ Reference Group } \\
\hline RG19- My friend has an impact on my choice of mobile phone. & & & 0.827 \\
\hline RG22- My social environment have an impact on my choice of mobile phone. & & & 0.810 \\
\hline RG21- The use of celebrities have an impact on my choice of mobile phone. & & & 0.789 \\
\hline RG18- My family have an impact on my choice of mobile phone. & & & 0.754 \\
\hline RG20- My groups of friends have an impact on my choice of mobile phone. & & & 0.844 \\
\hline Cronbach alpha $(\alpha)$ & 0.84 & 0.81 & 0.84 \\
\hline$\%$ of variance explained & 28.45 & 21.87 & 21.03 \\
\hline Total variance explained (\%) & \multicolumn{3}{|c|}{71.35} \\
\hline
\end{tabular}


Table 2: Mean, Standard Deviation, Correlations and Reliability

\begin{tabular}{|l|c|c|c|c|c|}
\hline \multicolumn{1}{|c|}{ Variable } & Mean & Sd & Brand trust & Purchase Intention & Reference Group \\
\hline Brand trust & 3.89 & 0.96 & $(.84)$ & & \\
\hline Purchase Intention & 3.68 & 1.10 & $0.58^{* *}$ & $(.87)$ & \\
\hline Reference Group & 2.80 & 1.19 & $0.133^{* *}$ & $0.189^{* *}$ & $(.84)$ \\
\hline
\end{tabular}

Table 3: Hierarchical Regression Analysis Results

\begin{tabular}{|c|c|c|c|c|c|c|c|c|c|}
\hline \multirow{2}{*}{ Step } & \multirow{2}{*}{ Variable } & \multicolumn{2}{|c|}{ Model 1} & \multicolumn{2}{|c|}{ Model 2} & \multicolumn{2}{|c|}{ Model 3} & \multicolumn{2}{|c|}{ Model 4} \\
\hline & & $\beta$ & $\mathbf{t}$ & $\beta$ & $\mathbf{t}$ & $\beta$ & $\mathbf{t}$ & $\beta$ & $\mathbf{t}$ \\
\hline 1 & $\begin{array}{l}\text { Gender } \\
\text { Marital Status } \\
\text { Age } \\
\text { Education } \\
\text { Income }\end{array}$ & $\begin{array}{r}.115 \\
-0.055 \\
-0.002 \\
-0.120 \\
0.243\end{array}$ & $\begin{array}{c}.167^{\star *} \\
-1.439 \\
-0.041 \\
-2.452^{\star *} \\
5.935^{\star *}\end{array}$ & $\begin{array}{c}.081 \\
-0.084 \\
.012 \\
-0.133 \\
.112\end{array}$ & $\begin{array}{c}2.696^{* *} \\
-2.673^{* *} \\
0.298 \\
-3.287^{* *} \\
3.253^{* *}\end{array}$ & $\begin{array}{r}0.070 \\
-0.083 \\
0.001 \\
-0.116 \\
0.106\end{array}$ & $\begin{array}{c}2.327^{* *} \\
-2.659^{* *} \\
0.015 \\
-2.845^{* *} \\
3.080^{* *}\end{array}$ & $\begin{array}{c}0.070 \\
-0.086 \\
0.001 \\
-0.108 \\
0.102\end{array}$ & $\begin{array}{c}2.337^{\star \star} \\
-2.772^{\star *} \\
-0.026 \\
-2.643^{\star \star} \\
2.983^{\star \star}\end{array}$ \\
\hline 2 & Brand trust & & & .561 & $18.790^{* *}$ & 0.553 & $18.448^{* *}$ & 0.535 & $17.630^{* *}$ \\
\hline 3 & \multicolumn{2}{|c|}{ Reference Group } & & & & 0.077 & $2.574^{* *}$ & 0.107 & $3.402^{\star \star}$ \\
\hline 4 & \multicolumn{2}{|c|}{$\begin{array}{l}\text { Brand trust } \mathrm{X} \\
\text { Reference group }\end{array}$} & & & & & & -0.094 & $-3.076^{\star \star}$ \\
\hline \multicolumn{2}{|c|}{ Model F } & \multicolumn{2}{|c|}{$13.094^{* *}$} & \multicolumn{2}{|c|}{$74.928^{* \star}$} & \multicolumn{2}{|c|}{$65.657^{* *}$} & \multicolumn{2}{|c|}{$59.289^{* \star}$} \\
\hline \multicolumn{2}{|c|}{ Total $\mathrm{R}^{2}$} & \multicolumn{2}{|c|}{0.081} & \multicolumn{2}{|c|}{0.377} & \multicolumn{2}{|c|}{0.383} & \multicolumn{2}{|c|}{0.391} \\
\hline \multicolumn{2}{|c|}{$\Delta R^{2}$} & \multicolumn{2}{|c|}{$0.081^{* *}$} & \multicolumn{2}{|c|}{$0.296^{* *}$} & \multicolumn{2}{|c|}{$0.006^{* *}$} & \multicolumn{2}{|c|}{$0.008^{* *}$} \\
\hline
\end{tabular}

Hierarchical regression analysis was used to determine the moderating effect of reference group on the relationship between brand trust and purchase intention. According to Baron and Kenny (1986), the influence of predictor and regulator variables seems to be the effect of regulation in the model in the case of the meaningful procedure of the predictive change. Moderating relationship was assessed using the product indicator where interaction terms were created by multiplying the indicators of the predictor and the moderator construct. The moderator and predictor were centered before performing multiplication.

When Table 3 is examined, it is seen that brand trust and reference group have a significant positive effect on purchase intention. In the light of these findings, hypotheses 1 and 2 are accepted.

The results of the hierarchical regression analysis summarized in Table 3 show that, the interaction term obtained by multiplying brand trust and reference group variables (brand trust $\mathrm{x}$ reference group) has a significant contribution to the model and suggests that reference group influence significantly moderates the relationship between brand trust and purchase intention

The moderating effect of reference group influence is demonstrated in Figure 1, which illustrates that the relationship between brand trust and purchasing intention differs according to the level of reference group influence. At lower levels of brand trust, high reference group influence leads to higher purchasing intention than low reference group influence does. At high brand trust level, however, both high and low reference group influence leads to the same purchasing intention level. In line with these findings, hypothesis 3 is accepted.

\section{Discussion and Conclusion}

As expected, brand trust was found to have a positive effect on purchasing intention. When buying a new phone, consumers favor a trusted brand in order to eliminate the instability arising from the diversity in the phone market and reduce the risks arising from the purchase. Thus, trust from users is seen as a tool that facilitates decision-making by reducing risk and uncertainty.

In the study, the role of the reference group in consumers' mobile phone purchase intention was lower than expected. It is assessed that young adults who completed the survey tend to make rational decisions about their purchases, or at least try to do so. Accordingly, rather than admit that mobile phone purchasing intentions are based on the influence of the social influence or the reference group, they believe that it is more rational and socially acceptable to explain with trust and commitment to the brand. 


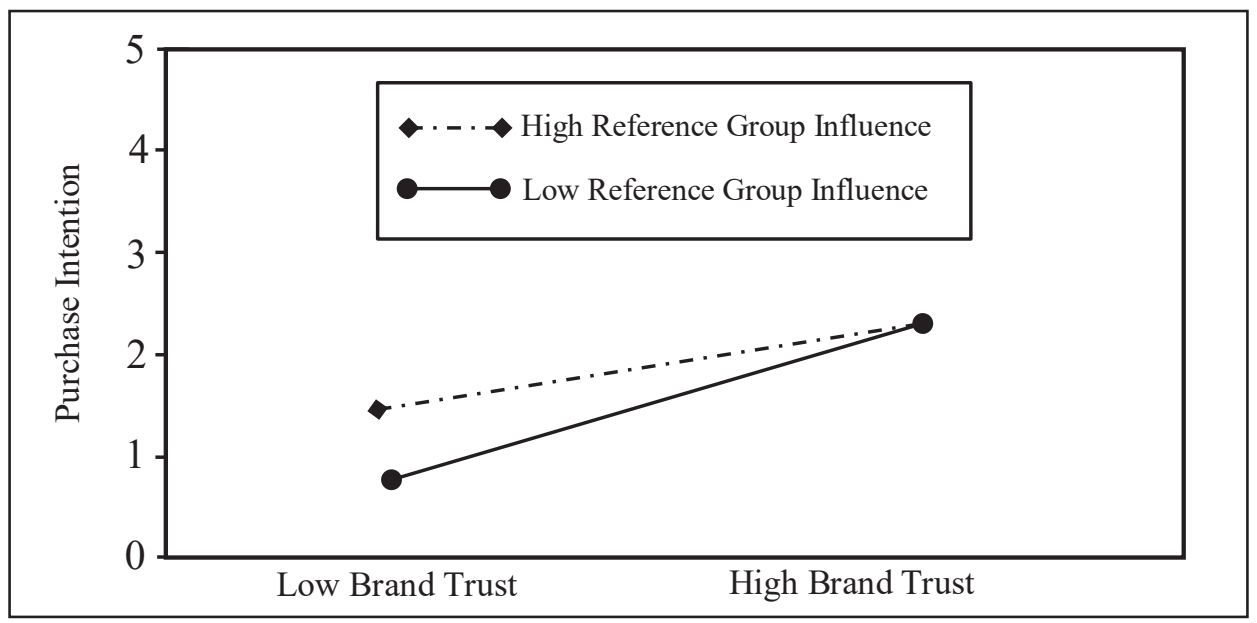

Figure 1: The relationship between brand trust and purchase intention

Repeated interactions and long-term relationships within the group emerge as trust-building keys. Hsu et. al (2006) found that $80 \%$ of individual purchasing decisions were made by influencing others' direct recommendations. Therefore, we can say that consumers believe that the information from others is more reliable and that they are making purchasing behavior in this direction.

When the research results are evaluated in terms of mobile phone manufacturers, Apple and Samsung are the two leading brands that come to the forefront in purchasing preferences. It is clear that these two brands are seen as a status symbol, as indicated by Lorente (2002), as well as building brand trust on users. When considered in this context, the fact that the producers are working to build trust in their brands will be able to provide a sustainable competitive advantage in the fierce competition.

\section{Research Limitations and Future Research}

In addition to the findings, the study has some limitations. Initially, the study was conducted on young adults aged 2030 years. Therefore, obtained data may not give accurate results for other age groups. For future research, if all age groups are included, the study will be more general. The research was conducted for the use of mobile phones that are used in the public area and in the special luxury consumption category. With a broad product range, it will be of great benefit to determine the product and application area of the effect of the reference group. The influence of personal and demographic factors such as age, gender, and income level on the purchasing behavior of the reference group has not been examined. In this sense, it will be useful to investigate the effect of the personal and demographic factors on the reference group. Finally, the impact of the reference group on purchasing intention may vary depending on cultural factors (Yang et al., 2007). For this reason, the studies in different cultures will be useful for a better understanding of the impact of the reference group on purchasing intention.

\section{References}

Afzal, H., Khan, M., Rehman, K., Ali, I., \& Wajahat, S. (2010). Consumer's trust in the brand: Can it be built through brand reputation, brand competence and brand predictability. International Business Research, 3(1), 43. DOI:10.5539/ibr. v3n1p43

Agustin, C., \& Singh, J. (2005). Curvilinear effects of consumer loyalty determinants in relational exchanges. Journal of Marketing Research, 62, 96-108.

Alhaddad, A. (2015). Perceived quality, brand image and brand trust as determinants of brand loyalty. Journal of Research in Business and Management, 3(4), 01-08.

Aytekin, A., Ayaz, A., \& Tüminçin, F. (2019). Investigation of smart phone usage of students of university. International Social Research and Behavioral Sciences Symposium, 298-305.

Baron, R. M., \& Kenny, D. A. (1986). The moderator-mediator variable distinction in social psychological research: Conceptual, strategic, and statistical considerations. Journal of Personality and Social Psychology, 51(6), 1173-1182.

Bayraktar, E., Tatoglu, E., Turkyilmaz, A., Delen, D., \& Zaim, S. (2012). Measuring the efficiency of customer satisfaction and loyalty for mobile phone brands with DEA. Expert Systems with Applications, 39(1), 99-106. https://doi.org/10.1016/j. eswa.2011.06.041.

Bearden, W. O., \& Etzel, M. J. (1982). Reference Group influence on product and brand purchase decisions. Journal of Consumer Research, 9(2), 183-194. https://doi.org/10.1086/208911. 
Bhattacharya, C., \& Sen, S. (2003). Consumer company identification: A framework for understanding. Journal of Marketing, 67(2), 76-88.

Bourne, F. (1957). Group influence in marketing and public relations. Some Applications of Behavioral Research, 207-255.

Chaudhuri, A., \& Holbrook, M. B. (2001). The chain of effects from brand trust and brand affect to brand performance: The role of brand loyalty. Journal of Marketing, 65(2), 81-93.

Chiu, C. M., Huang, H. Y., \& Yen, C. H. (2010). Antecedents of online trust in online auctions. Electronic Commerce Research and Application, 9(10), 148-159. https://doi.org/10.1016/j. elerap.2009.04.003.

Dehghani S. M., Mohamamdi, A., Pour, A. Y., \& Sayeh, M. K. (2013). Investigation of factors which affect evaluation of consumers attitude to brand development. Journal of Business Management, 5(1), 85-104.

Delgado, B. E., \& Munuer, A. J. L. (2005). Does brand trust matter to brand equity? Journal of Product and Brand Management, 14(3), 187-196. https://doi.org/10.1108/10610420510601058.

Doyle, P. (2001). Shareholder-value-based brand strategies. Journal of Brand Management, 9(1), 20-30.

Eze, U. C., Chin, C. H., \& Lee, C. H. (2012). Purchasing designer label apparels: The role of reference groups. Asian Journal of Business Research, 2(2), 52-74. https://doi.org/10.14707/ ajbr.120010.

Fornell, C., Larcker, D. F. (1981), Evaluating structural equation models with unobservable variables and measurement error. Journal of Marketing Research, 18(1), 39-50.

Goh, S. K., Jiang, N., \& Tee, P. L. (2016). The Impact of brand trust, self-image congruence and usage satisfaction toward smartphone repurchase intention. International Review of Management and Marketing, 6(3), 436-441.

Harris, L. C., \& Goode, M. M. (2004). The four levels of loyalty and the pivotal role of trust: A study of online service dynamics. Journal of Retailing, 18(1), 139-158. http://www.jstor.org/ stable/3151312.

Hawass, H. (2013). Brand trust: implications from consumer doubts in the Egyptian mobile phone market. Journal of Islamic Marketing, 4(1), 80-100. https://doi. org/10.1108/17590831311306363.

Hegner, S. M., \& Jevons, C. (2016). Brand trust: A cross-national validation in Germany, India, and South Africa. Journal of Product \& Brand Management, 25(1), 58-68. https://doi. org/10.1108/JPBM-02-2015-0814.

Hegner, S., Beldad, A., \& Heghuis, S. (2014). How company responses and trusting relationships protect brand equity in times of crises. Journal of Brand Management, 21(5), 429-445. https://doi.org/10.1057/bm.2014.12.

Hess, J., \& Story, J. (2005). Trust-based commitment: Multidimensional consumer-brand relationships. Journal of Consumer Marketing, 22(6), 313-322. https://doi. org/10.1108/07363760510623902
Hiscock, J. (2001). Most trusted brands. Marketing, 1(3), 32-33.

Hsu, C. H., Kang, S. K., \& Lam, T. (2006). Reference group influences among Chinese travelers. Journal of Travel Research, 44(4), 474-484.

Indayani, L. (2016). The influence of reference group and brand awareness of buying interest smartphone in galery erafone giant suncity departmentstore sidoarjo. National Seminar on Business Economics, 7(3), 11-22. https://doi. org/10.1177/0047287505282951.

Kumar M. M., Kesharwani, A., \& Das, D. (2016). The relationship between risk aversion, brand trust, brand affect and loyalty: Evidence from the FMCG industry. Journal of Indian Business Research, 7(2), 78-97. https://doi.org/10.1108/JIBR-04-20150045 .

Laroche, M., Habibi, M. R., Richard, M. O., \& Sankaranarayanan, R. (2012). The effects of social media based brand communities on brand community markers, value creation practices, brand trust and brand loyalty. Computers in Human Behavior, 28(5), 1755-17.

Leigh, J. H. (1989). An extension of the bourne typology of reference group influence on product-related decisions. Journal of Business and Psychology, 4(1), 65-85. https://doi. org/10.1007/BF01023039.

Lin, C. T., Wang, S. M., \& Hsieh, H. Y. (2003). The brand-switching behaviour of Taipei female consumers when purchasing UV skincare products. International Journal of Management, 20(4), 443-452.

Lorente, S. (2002). Youth and mobile telephones: More than a fashion. Revista de Estudios de Juventud, 57(2), 9-24.

Luk, S. T., \& Yip, L. S. (2008). The moderator effect of monetary sales promotion on the relationship between brand trust and purchase behaviour. Journal of Brand Management, 15(6), 452-464. https://doi.org/10.1057/bm.2008.12.

MacKenzie, S. B., Podsakoff, P. M., \& Podsakoff, N. P. (2011). Construct measurement and validation procedures in MIS and behavioral research: Integrating new and existing techniques. MIS quarterly, 35(2), 293-334.

Marangoz, M. (2013). Buy with consumers 'perception of brand functions the relationship between post-receiving behavior. Journal of Dokuz Eylul University Faculty of Economics and Administrative Sciences, 21(2).

Noguti, V., \& Russell, C. A. (2014). Normative influences on product placement effects: Alcohol brands in television series and the influence of presumed influence. Journal of Advertising, 43(1), 46-62. https://doi.org/10.1080/00913367.2013.810557.

Nguyen, H. C., \& Do, D. T. (2020). Factors influencing the perception of the selling price of luxury apartments. Journal of Asian Finance, Economics, and Business, 7(5), 185-194. https://doi.org/10.13106/jafeb.2020.vol7.no5.185

Ogunyemi, O. (2006). Consumption and (in) appropriate use of mobile phone among teenage Africans in the UK. In Proceedings of the 2nd International Conference on Pluridisciplinary Perspectives on Child and Teen Consumption, (pp. 104-118). 
Park, C., \& Lessig, V. P. (1977). Students and housewives: Differences in susceptibility to reference group influence. Journal of Consumer Research, 4(2), 102-110.

Permatahati, D. I. (2013). Lifestyle, reference group, and attitude purchasing food packaged products (Case study: Housewives in Bogor rural and urban areas)] (Undergraduate thesis). Retrieved from http://repository.ipb.ac.id/ bitstream/handle/123456789/67380/I13dip.pdf?sequence= 1 \&isAllowed $=\mathrm{y}$.

Puriwat, W., \& Hoonsopon, D. (2016). The effect of reference groups on purchase intention: evidence in distinct types of shoppers and product involvement. Australasian Marketing Journal, 24(2), 157-164. https://doi.org/10.1016/j.ausmj.2016.05.001.

Rehman, A., \& Jamil, S. A. (2016). Influence of income and occupation on consumers' susceptibility to reference group demands on brand choice decisions. International Review of Management and Marketing, 6(2), 376-382.

Rempel, J. K., Holmes, J. G., \& Zanna, M. P. (1985). Trust in close relationships. Journal of Personality and Social Psychology, 49(1), 95-112. https://doi.org/10.0022-35 WS5/J00.75.

Sichtmann, C. (2007). An analysis of antecedents and consequences of trust in a corporate brand. , European Journal of Marketing, 41(9), 999-1015. https://doi.org/10.1108/03090560710773318.

Sirdeshmukh, D., Singh, J., \& Sabol, B. (2002). Consumer trust, value, and loyalty in relational exchanges. Joumal of Marketing, $6(1), 15-37$.

Sodano, V. (2002). Trust, economic performance and the food system: can trust lead up to unwanted results? Paradoxes in food chains and networks. In:Proceedings of the 5th International Conference on Chain and Network Management in Agribusiness and the Food Industry, (pp. 104-118). Netherlands.

Sousa, A., Nobre, H., \& Farhangmehr, M. (2019). Cosmopolitanism and the Mediating effect of country image on consumers' purchase, visit and investment intentions. Journal of Asian Finance, Economics and Business, 6(4), 159-170. https://doi. org/10.13106/jafeb.2019.vol6.no4.159

Srivastava, L. (2005). Mobile phones and the evolution of social behaviour. Behaviour and Information Technology, 24(2), 111129. https://doi.org/10.1080/01449290512331321910.

Susanto, A. B. (2016). The influence of cultural, social, personal, and psychological on consumer purchase decision-study on tonasa cement product in manado city. Jurnal Berkala Ilmiah Efisiensi, 16(1). 198-206.
Sweeney, J. C., \& Soutar, G. N. (2001). Consumer perceived value: The development of a multiple item scale. Journal of Reailing, 77(2), 203-220.

Şimşek, G. G., \& Noyan, F. (2009). A model of brand loyalty in Turkish cellular phone market. Middle East Technical University Studies in Development, 36(1). 121-198.

Tsai, Y. H., Joe, S. W., Lin, C. P., Chiu, C. K., \& Shen, K. T. (2015). Exploring corporate citizenship and purchase intention: Mediating effects of brand trust and corporate identification. Business Ethics: A European Review, 24(4), 361-377. https:// doi.org/10.1111/beer.12073.

TUIKK. (2020). Turkish Statistical Institute, Retrieved May 30, 2020, http://www.tuik.gov.tr/PreTablo.do?alt_id=1028.

Wang, Y., \& Lee, C. C. (2016). Does winning an award matter to brand trust and purchase intention?-evidence from Franklin Templeton Investments. Journal of Business and Economic Policy, 3(1), 75-81.

White, K., \& Dahl, D. W. (2006). To be or not be? the influence of dissociative reference groups on consumer preferences. Journal of Consumer Psychology, 16(4), 404-414. http://www. acrwebsite.org/volumes/12972/volumes/ap07/AP-07.

Wottrich, V. M., Verlegh, P. W., \& Smit, E. G. (2017). The role of customization, brand trust, and privacy concerns in advergaming. International Journal of Advertising, 36(1), 6081. https://doi.org/10.1080/02650487.2016.1186951.

Yang, J., He, X., \& Lee, H. (2007). Social reference group influence on mobile phone purchasing behaviour: A crossnation comparative study. International Journal of Mobile Communications, 5(3), 319-338.

Yannopoulou, N., Koronis, E., \& Elliott, R. (2011). Media amplification of a brand crisis and its affect on brand trust. Journal of Marketing Management, 27(5), 530-546. https://doi. org/10.1080/0267257X.2010.488141.

Yiğit, Y. E. (2019). The effect of smartphone addiction on loneliness in adolescents. Master's thesis. İstanbul, Turkey: Biruni University Institute of Health Sciences.

Zboja, J., \& Voorhees, C. (2006). The impact of brand trust and satisfaction on retailer repurchase intentions. Journal of Services Marketing, 20(5), 381-390. https://doi. org/10.1108/08876040610691275. 